\title{
Successful Treatment of Two Children's with Refractory Immune Thrombocytopenic Purpura with Eltrombopag
}

\author{
Baris Yilmaz*, Ayse Gulnur Tokuc and Ahmet Koc
}

Marmara Universitesi Egitim ve Arastirma Hastanesi, Turkey

Submission: February 09, 2018; Published: July 10, 2018

*Corresponding author: Baris Yilmaz, MD, Marmara Universitesi Egitim ve Arastirma Hastanesi, Pediatric Hematology and Oncology Pendik Istanbul, Turkey, Email: drbyilmaz@windowslive.com

\section{Abstract}

Immune thrombocytopenic purpura (ITP) is most common etiologic factor of thrombocytopenia in childhood. ITP is a usually spontaneously resolves phenomenon. But sometimes they can be so cruel desperate physicians to leave. Refractory ITP patient's treatment is controversial. Eltrombopag an oral used, good alternative in the future with refractory ITP cases. We want to present two pediatric ITP patients in whom standard treatment is not effective. These patients had no response to current conventional therapy protocols. Eltrombopag appears to be effective for treating pediatric refractory immune thrombocytopenic purpura. We did not observe any significant side effects in both cases.

Keywords: Refractory immune; Thrombocytopenic; Eltrombopag; Purpura; Pediatric; Megakaryocytes

Abbrevations: ITP: Immune Thrombocytopenic Purpura; Tpo: Thrombopoietin; TpoR: Thrombopoietin Receptor

\section{Introduction}

Immune thrombocytopenic purpura (ITP) is an acquired autoimmune disorder that affects children and adults. It is characterized by isolated thrombocytopenia with a peripheral blood platelet count $<100 \times 109 / \mathrm{L}$, and all other secondary causes must be excluded [1]. Definition of newly diagnosed ITP; within three months from diagnosis, persistent ITP; between three to 12 months from diagnosis, chronic ITP; when the disease lasts for more than 12 months [2].

Eltrombopag is an orally bioavailable, thrombopoietin receptor agonist. It is first member of this class, and induces the differentiation of bone marrow platelets, megakaryocytes, and megakaryocyte precursor cells patients with thrombocytopenia [3].Eltrombopag and thrombopoietin (Tpo) connect to an individual of the thrombopoietin receptor (TpoR) domains. So, eltrombopag effect is dependent to TpoR but independent from Tpo.

There are very few reports associated with eltrombopag use in children with ITP $[4,5]$.

\section{Patient 1}

A seven-year-old white male patient presented with spontaneous ecchymosis at legs and generalized petechial and purpuric lesions. In history, he had acute, non-specific upper respiratory tract infection one week ago. Physical examination was normal except cutaneous brushing and spotting. Complete blood

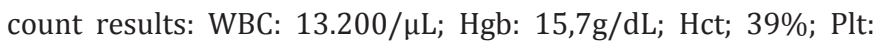
4.000/ $\mu \mathrm{L}$; MPV: 10,7 FL. Routine biochemical tests was normal.

\section{Coagulation tests}

e.g. PT, APTT, INR, fibrinogen and d-dimer was in normal limits. The patient was hospitalized with diagnosis of ITP. Intravenous immune globulin (IVIg) therapy was given for two consecutive days, dosage was $1 \mathrm{~g} / \mathrm{kg} /$ dose. Platelet count raised to $250.000 /$ $\mu \mathrm{L}$ at third day, he was discharged from hospital. But in followup, platelet count decreased from week to week, and was 19.000/ $\mu \mathrm{L}$ at the end of two months. He was asymptomatic and had no physical findings suggesting thrombocytopenia. Approximately one year later, after an upper airway tract infection platelet count 
decreased to $6.000 / \mu \mathrm{L}$. Bone marrow aspiration was performed to him, except slightlyraised megakaryocytes normal bone marrow findings were observed.Methyl-prednisolone $30 \mathrm{mg} / \mathrm{kg} /$ day applied for the first three consecutive days and then $20 \mathrm{mg} / \mathrm{kg} /$ day during the following four days. The patient's response to pulse steroid therapy was not satisfactorily.

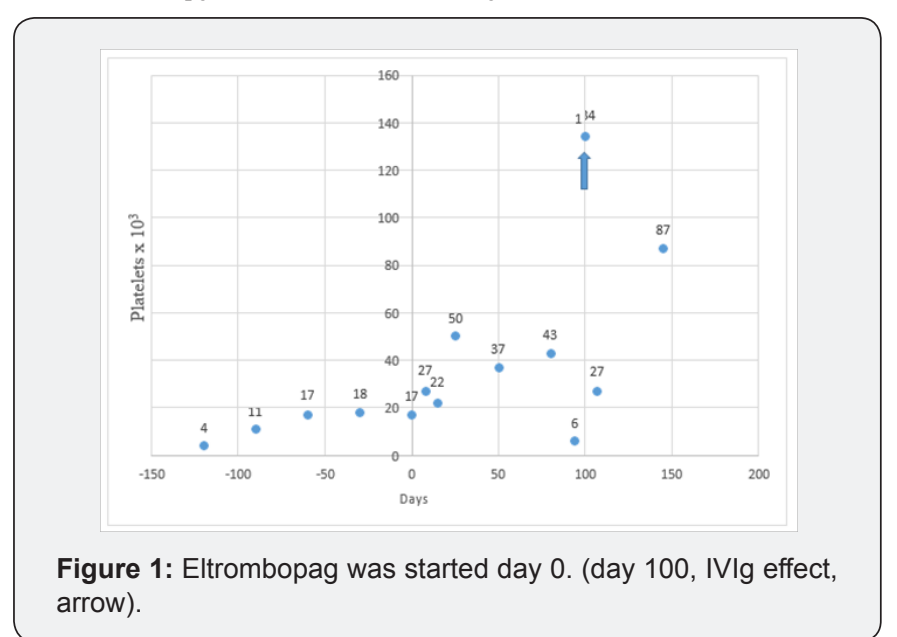

Then treatment was continued with $1-2 \mathrm{mg} / \mathrm{kg} /$ day prednisolone PO. Because of a lot of side effects like hypertension, central obesity, osteonecrosis, osteoporosis, depression developed while receiving steroid therapy, it was tapered and ceased. Treatment with rituximab (dosage: $375 \mathrm{mg} /$ dose/week for four weeks) was given. We waited 6months for rituximab's effect and did not get enough response. After the standard vaccination program against to encapsulated bacterial agents was given and penicillin prophylaxis was started, he was referred to pediatric surgeon for splenectomy. After the splenectomy platelet counts raised rapidly to $1.184 \times 109 / \mathrm{L}$. But this blissfully days was too short. We have tried alternative immunosuppressive therapies such as cyclosporine, azathioprine. Unfortunately, we did not observe any response to these immunosuppressive agents. He was referred to recurrent periods IVIg therapy responsive, but despite decreased in platelet count was observed in a very short time. After three years and 5 months from the diagnosis, $50-75 \mathrm{mg} /$ day eltrombopag $(0,75-1,14 \mathrm{mg} / \mathrm{kg} /$ day $)$ was started. Platelet counts exceeded $30.000 / \mu \mathrm{L}$ within two weeks. This patient was in need ofIVIg treatment only once time in six months (day 100) (Figure 1), and we have not observed any side-effect.

\section{Patient 2}

A seven-year-old white female was referred to our clinic with easy brushing and nose bleeding. Her complains emerged during last week. Personal history and familial history was nonspecific. Only pathological physical examination finding was ecchymotic areas all over the body. Laboratory studies on admission revealed the following values: WBC: $11.800 / \mu \mathrm{L} ; \mathrm{Hgb}: 12,7 \mathrm{~g} / \mathrm{dL}$; Plt: $3.000 /$ $\mu \mathrm{L}$; MPV: 8,7FL. Coagulometric and biochemical tests was normal. Bone marrow examination confirmed ITP. We started high dose methyl-prednisolone treatment (as mentioned above). A very fast response was received within the first week and platelet numbers exceeded $500 \times 109 / \mathrm{L}$. At the first month after diagnosis she had no problem, but during the following months the number of platelets decreased steadily. All treatment protocols that are explicitly specified in the first patient was tried on this patient.

But we did not observe an objective response except temporary response to IVIg lasting for several days. Splenectomy was performed at the 14th month of diagnosis but we observed no response a for target, safe platelet levels. Two months after splenectomy, we started eltrombopag therapy regimen $50-75 \mathrm{mg} /$ day $(1-1,5 \mathrm{mg} / \mathrm{kg} /$ day). We make dose adjustments according to the number of platelets. She had needed two times IVIg therapy, (-30, day 29 and 180) (Figure 2). This time were in post-infectious periods. This patient has been followed for nearly a year without any problem and side-effects.

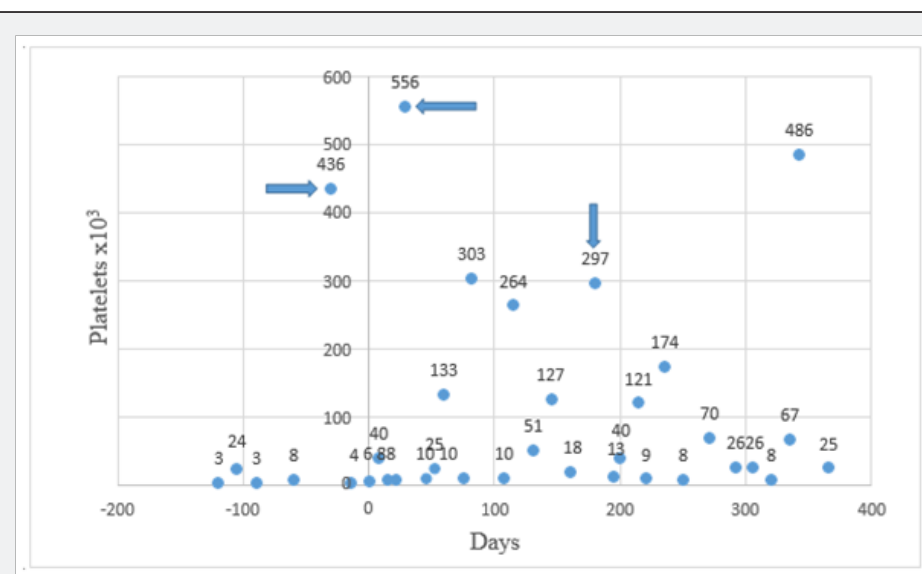

Figure 2: Eltrombopag was started day 0. (day -30, 29 and 180, IVIg effect, arrows).

We did to adjust the eltrombopag dose each patient in the following way; initial dosage: $75 \mathrm{mg} /$ day, if control platelet level between 10-50 x 109/L, continue 75mg/day, if platelet level $>50 \times$
$109 / \mathrm{L}$; dosage reduced to $50 \mathrm{mg} /$ day. If platelet level below to $10 \mathrm{x}$ 109/L and no bleeding symptoms continue $75 \mathrm{mg} /$ day, plt< 109/L plus bleeding symptoms, addition to supportive IVIg therapy. 


\section{Discussion}

We have seen quite good results in two of our patients. We have shown eltrombopag can be effective to increase platelet counts in children with refractory and chronic ITP. It was reported that frequently observed side effects of eltrombopag are headache, abdominal pain, diarrhea, nausea, vomiting; and adverse events are anemia, neutropenia, and transaminasemia. But the drug was well tolerated by our patients and we have not observed any sideeffect or events.

Cheng et al. [6] first randomized, phase 3, double-blind, placebo-controlled study in adults with chronic-refractory ITP [6]. The end of RAISE study was 6 month treatment period responded shown $79 \%$ in eltrombopag vs $28 \%$ in placebo group ( $p<0.0001$ ). Only two patients receiving eltrombopag group thromboembolic events and these patients have extra risk factors. The other side effects were observed in both groups and as mild.

Eltrombopag was second attempted in 2008 for the treatment of adult refractory and chronic ITP. A total of $85 \%$ of patients' platelets raised to $50000 / \mu \mathrm{L}$. Eltrombopag well tolerated; the most common side effects were headache, nasopharyngitis, upper respiratory tract infection, and fatigue. Eltrombopag was not effective in $10 \%$ of the patients in this study [7].

The first randomized, multicenter, placebo-controlled, doubleblind pediatric study was done by Bussel et al.[4] and it was shown that eltrombopag has high effectivity (62\%) vs. placebo (32\%), $(p=0,011)$. Platelet counts began to increase after one week in this study. The efficacy of eltrombopag in the treatment of pediatric persistent and refractory ITP very hopeful and the results similar to adult studies [4].

The first phase 3, randomized, pediatric clinical trial was PETIT2 study. This trial results shown that $40 \%$ of patients who received eltrombopag compared with $3 \%$ of patients who received placebo achieved the platelet counts of at least $50 \times 10^{9} / \mathrm{L}$ [8]. The side-effect profile of eltrombopag in PETIT2 is similar to the PETIT study and adult studies.
The early to reach a definite conclusion yet; better efficacy and much more less side effects observed eltrombopag treatment due to other second treatment options. We think that eltrombopag treatment should be tried, before splenectomy and heavy immunosuppressive therapy. Although we still believe that there is a need for more controlled studies.

\section{Acknowledgement}

The authors are acknowledging to both patients who agreed to take part in this article.

\section{References}

1. Wilson DB (2015) Acquired Platelet Defects. In: Orkin SH, et al., In: Nathan and Oski's Hematology and Oncology of Infancy and Childhood (8 ${ }^{\text {th }}$ Edn), United States: Saunders., USA, pp. 1076-1102.

2. Rodeghiero F, Stasi R, Gernsheimer T, Michel M, Provan D, et al. (2009) Standardization of terminology, definitions and outcome criteria in immune thrombocytopenic purpura of adults and children: report from an international working group. Blood 113(11): 2386-2393.

3. Erickson-Miller CL, DeLorme E, Tian SS, Hopson CB, Landis AJ, et al. (2009) Preclinical activity of eltrombopag (SB-497115), an oral, nonpeptide thrombopoietin receptor agonist. Stem Cells 27(2): 424430.

4. Bussel JB, Miguel PG de, Despotovic JM, Grainger JD, Sevilla J, et al. (2015) Eltrombopag for the treatment of children with persistent and chronic immune thrombocytopenia (PETIT): a randomised, multicentre, placebo-controlled study. Lancet 2(8): 0e315-e325.

5. Wang X, Li A (2016) Successful use of eltrombopag in a child with refractory immune thrombocytopenia: case study and literature review. Blood Coagul Fibrinolysis 27(7): 825-827.

6. Cheng G, Saleh MN, Marcher C, Vasey S, Mayer B, et al. (2011) Eltrombopag for management of chronic immune thrombocytopenia (RAISE): a 6-month, randomised, phase 3 study. Lancet 377(9763): 393-402.

7. Bussel JB, Saleh MN, Wong RSM, Burgess P, Bakshi K, et al. (2013) Update on the safety and efficacy of EXTENDed treatment with eltrombopag (EPAG) in adults with chronic immune thrombocytopenia (ITP). Blood 122: 2315.

8. Grainger JD, Locatelli F, Chotsampancharoen T, Donyush E, Pongtanakul B, et al. (2015) Eltrombopag for children with chronic immune thrombocytopenia (PETIT2): a randomised, multicentre, placebocontrolled trial. Lancet 386(100084): 1649-1658.

\section{Your next submission with Juniper Publishers will reach you the below assets}

- Quality Editorial service

- Swift Peer Review

- Reprints availability

- E-prints Service

- Manuscript Podcast for convenient understanding

- Global attainment for your research

- Manuscript accessibility in different formats

( Pdf, E-pub, Full Text, Audio)

- Unceasing customer service

Track the below URL for one-step submission https://juniperpublishers.com/online-submission.php 